\title{
Qualitative Analysis of Groundwater from Nandgaon Peth Village District Amravati, Maharashtra
}

\author{
${ }^{1}$ Jaishree S. Karmore, ${ }^{* 2}$ Rajni Kant \\ 1,2 Department of Mining Engineering, Ballaepur Institute of Technology, Ballarpur- 442701, Maharashtra State \\ Email:jayakarmore@gmail.com,rajnikantlog@gmail.com
}

Received: 22nd October 2019, Accepted: 31st January 2020, Published: 29th February 2020

\begin{abstract}
The water quality of Nandgaon peth village of Amravati city, Maharashtra was studied for physical chemical and biological parameter like temperature, $\mathrm{pH}$, conductivity acidity, Hardness, total dissolved solid chloride was found that water sample collected from Nandgaon peth village dug well sample. Most of the parameters, not observed within the permissible limits as describe by various agencies. The quality of water was useful for drinking and agricultural purposes. Water quality determines the goodness of water for particularly purpose. Water quality test give will information about the health of the waterway. The change of quality of water can be seen by testing water over the period of time. Parameter may be tested include temperature, Alkalinity, Acidity, $\mathrm{CO}$, $\mathrm{PH}$, Hardness, calcium , and calcite chloride. An assessment of the aquatic micro invertebrates can be provided and indicates water quality of groundwater.
\end{abstract}

\section{Keywords \\ Ground Water Quality, Biological Effect, Physico- Chemical Analysis}

\section{Introduction}

Water quality is the term used to describe the chemical, physical and biological characteristic of water with respect to its suitability of a particular use of drinking and agriculture [15]. Nandgaon Peth village of Amravati District is suffering from shortage of groundwater due to lowering of water table, excess extraction of the same for domestic and agriculture purposes and localized occurrences of groundwater salinity [1]. The area is a small part of Purna and Pedhi river basin. The aim of the work is to interpret the groundwater condition, water quality and to prepare a detailed hydro-geological report for management of groundwater resource of the area [12]. The study was planned during the period of October 2017 to June 2018. The generated water use for irrigation of the field and vicinity of stream water [9]. These water characterize by different physic-chemico and biological parameters compairizing the observation with standard prescription by the Central Pollution Control Board (CPCB) and World Health Organization (WHO), with regards quality of water for domestic and agricultural concerning parameters were $\mathrm{pH}$, acidity, alkalinity, $\mathrm{CO}$, chloride, calcium, hardness. All the parameters are independent, the water quality show the majority of the parameters are found within non-permissible limit, increasing the demand of water for irrigation exceed the available water supply. The present investigation is concerned with the routine practice of domestic and agricultural source of water [13]. Therefore, necessary to carry on physical- chemical and biological analysis of domestic and agricultural well water quality. The water sample was made by composite sampling method. The consecutive sampling site are at a distance of $2 \mathrm{kms}$ from each others. Population of Nandgaon Peth villages are suffering from shortage of ground water. Need of water can't be fulfill by the only source of groundwater for entire population. The level of ground water decreasing in this duration of October 2017 to June 2018. The domestic and agricultural problems are created to the population in this villages [7]. 


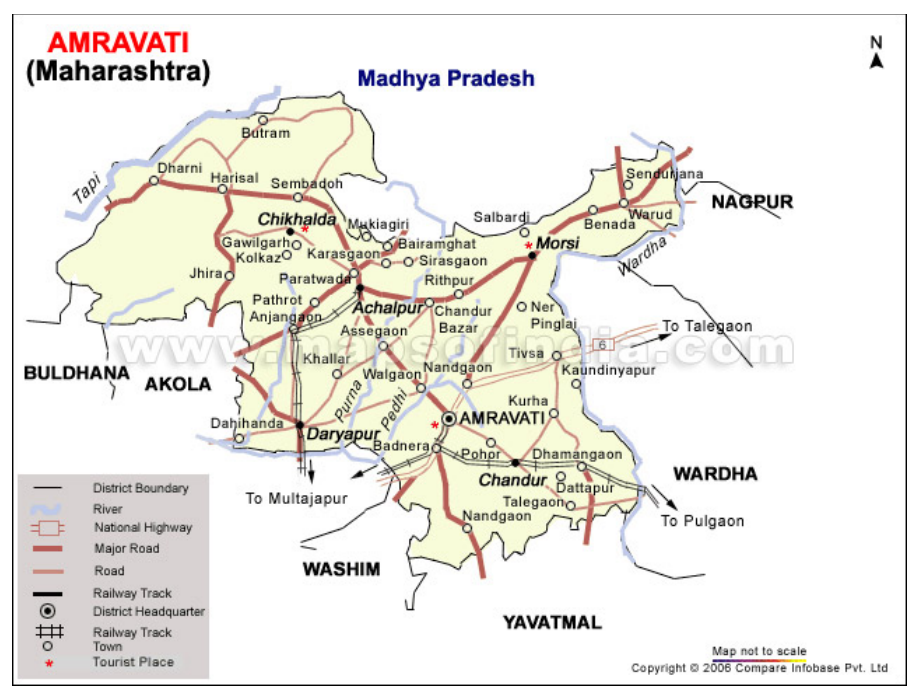

\section{Stratigraphy}

Fig 1: Map of the Amravati District Showing Location of Nandgaon Peth Village

The Purna river alluvial and Pedhi river basin is one of the intracratoioc basins of India. Mainly filled by sand, siltstone, clay, boulder etc. the basin extends roughly in E-W direction for about $170 \mathrm{~km}$ while its maximum width is $55 \mathrm{~km}$ along. The other end of the basin is a part of foot hills of Satpura and mostly demarcated by structural feature.

the sediment are also of the coarce grained nature i.e boulder beds. However, a general decrease of grain size is notice toward the south. The entitre basin is mostly surrounded by Deccan Trap. A few of the patches of Gondwana and Lameta are exposed in extreme.

Following table shown by Stratigraphy of Nandgaon Peth village.

\section{General Geological Succession:}

\begin{tabular}{|c|c|c|}
\hline Age & Formation & Lithology \\
\hline $\begin{array}{l}\text { Pleistocene } \\
\text { Boulder layer }\end{array}$ & Alluvium & Soil, Silt, Clay, Recent \\
\hline \multicolumn{3}{|c|}{ 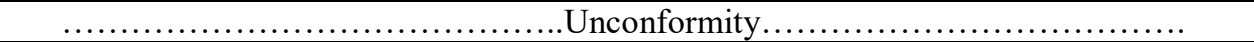 } \\
\hline $\begin{array}{l}\text { Upper Cretaceous } \\
\text { To Eocene }\end{array}$ & Deccan Trap & Basalt \\
\hline \multicolumn{3}{|c|}{ 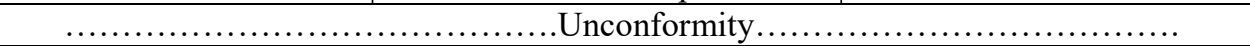 } \\
\hline Upper Cretaceous & Lameta & $\begin{array}{c}\text { Limestone } \\
\text { Clay, Sandstone }\end{array}$ \\
\hline \multicolumn{3}{|c|}{ Unconformity. } \\
\hline $\begin{array}{c}\text { Midddle Cretaceous } \\
\text { To Permian }\end{array}$ & Gondwana super group & Sandstone \\
\hline \multicolumn{3}{|c|}{ 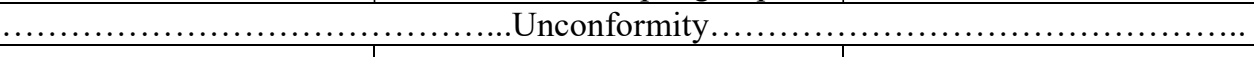 } \\
\hline Proterozoic & -------------- & Feldspathic Gneiss \\
\hline
\end{tabular}

\section{Table 1: Geological Succession of Village}

\section{Location of the Area}

The study of area comprising of Nandgaon Peth village in Amravati District lying between Latitude $20.9927^{0}$ to $21.0217^{\circ} \mathrm{N}$ and longitude $77.8379^{\circ}$ to $77.8239^{\circ} \mathrm{E}$ and is covered in survey of India. This village lies at about $14 \mathrm{~km}$ north to the District headquarter Amravati ( fig 1).

\section{Methodology}

Methodology followed includes collection of data on hydrology, well inventory and recharge condition, types of aquifer and depth of weathering. All this information were collected from ground water survey and development agency (GSDA) Amravati the laboratory data include determination of physical and chemical 
parameters of 16 samples covering the entire area in a uniform manner. The physical evaluation includes. $\mathrm{PH}$, and temperature whereas, later incorporates acidity, alkalinity, $\mathrm{CO} 2$, chloride, Calcium and hardness of water, temperature [2]. The analytical data and its graphical representation are provided in the table 2 and fig. 2 respectively. Sample collected by different places of Nandgaon peth village and analysis in different parameters are shown the result in table no. 2.

\begin{tabular}{|c|l|c|c|c|c|c|c|c|c|c|}
\hline $\begin{array}{c}\text { S. } \\
\text { No } \\
\cdot\end{array}$ & \multicolumn{1}{|c|}{$\begin{array}{c}\text { Name of } \\
\text { villages }\end{array}$} & $\begin{array}{c}\text { Water } \\
\text { table } \\
\text { height } \\
\mathbf{m} \text { ) }\end{array}$ & $\mathbf{p H}$ & $\begin{array}{c}\mathbf{T e m p .} \\
\mathbf{t}^{\mathbf{0}}\end{array}$ & $\begin{array}{c}\text { Acidity } \\
\mathbf{m g} / \mathbf{l t}\end{array}$ & $\begin{array}{c}\text { Alkalinit } \\
\mathbf{y} \mathbf{~ m g} / \mathbf{l t}\end{array}$ & $\mathbf{C O}_{\mathbf{2}}$ & $\begin{array}{c}\text { Chloride } \\
\mathbf{m g} / \mathbf{l t}\end{array}$ & $\begin{array}{c}\text { Calcium } \\
\mathbf{m g} / \mathbf{l t}\end{array}$ & $\begin{array}{c}\text { Hardnes } \\
\mathbf{s ~ m g / l t}\end{array}$ \\
\hline 1 & Asaramandir & 4.22 & 7.04 & 27.6 & 152 & 298 & 132 & 176.5 & 32.08 & 150 \\
\hline 2 & Telipura & 5.6 & 7.02 & 28.6 & 60 & 267 & 56.8 & 185.7 & 16.07 & 173 \\
\hline 3 & Yawalpura & 5.9 & 7.02 & 29.9 & 101 & 256 & 88 & 134.8 & 32.05 & 181 \\
\hline 4 & Gajanannagar & 11.34 & 7.03 & 27.5 & 83 & 287 & 70.8 & 128.8 & 48.08 & 151 \\
\hline 5 & Bhuskale form & 7.9 & 7.07 & 28.7 & 40 & 193 & 35.7 & 160.4 & 20.04 & 162 \\
\hline 6 & Chale form & 7.19 & 7.01 & 26.8 & 53 & 160 & 44.5 & 113.8 & 16.07 & 150 \\
\hline 7 & Rathi form & 7.14 & 7.23 & 26.7 & 80 & 182 & 70.4 & 142 & 12.08 & 150 \\
\hline 8 & Bhasmeform & 4.7 & 7.36 & 27.2 & 85 & 200 & 70.3 & 106.5 & 57.13 & 141 \\
\hline 9 & $\begin{array}{l}\text { Near police } \\
\text { station }\end{array}$ & 3.65 & 7.32 & 26.5 & 187 & 130 & 154.8 & 177.6 & 190 & 180 \\
\hline 10 & Gauri restaurant & 1.55 & 7.05 & 28.9 & 142 & 254 & 124.2 & 156.3 & 174 & 190 \\
\hline 11 & Agrawal land & 2.65 & 7.27 & 26.8 & 153 & 250 & 132.5 & 181.7 & 179 & 168 \\
\hline 12 & Borwar farm & 4.75 & 7.25 & 26.6 & 93 & 235 & 79.2 & 106.8 & 134 & 170 \\
\hline 13 & Wankhade farm & 3.3 & 7.42 & 27.4 & 56 & 200 & 44.2 & 134.7 & 120 & 130 \\
\hline 14 & Bobade Farm & 2.78 & 7.06 & 26.9 & 90 & 160 & 70.4 & 184.9 & 12.09 & 122 \\
\hline 15 & KhanapurSquar & 8.6 & 7.48 & 27.9 & 134 & 244 & 114.4 & 165.5 & 8.04 & 160 \\
\hline 16 & $\begin{array}{l}\text { Bharat Petrol } \\
\text { Pump }\end{array}$ & 3.8 & 7.65 & 26.7 & 138 & 240 & 79.3 & 120.8 & 16.04 & 121 \\
\hline
\end{tabular}

Table 2: Well Inventory Data and Analysis Data of Water Sample

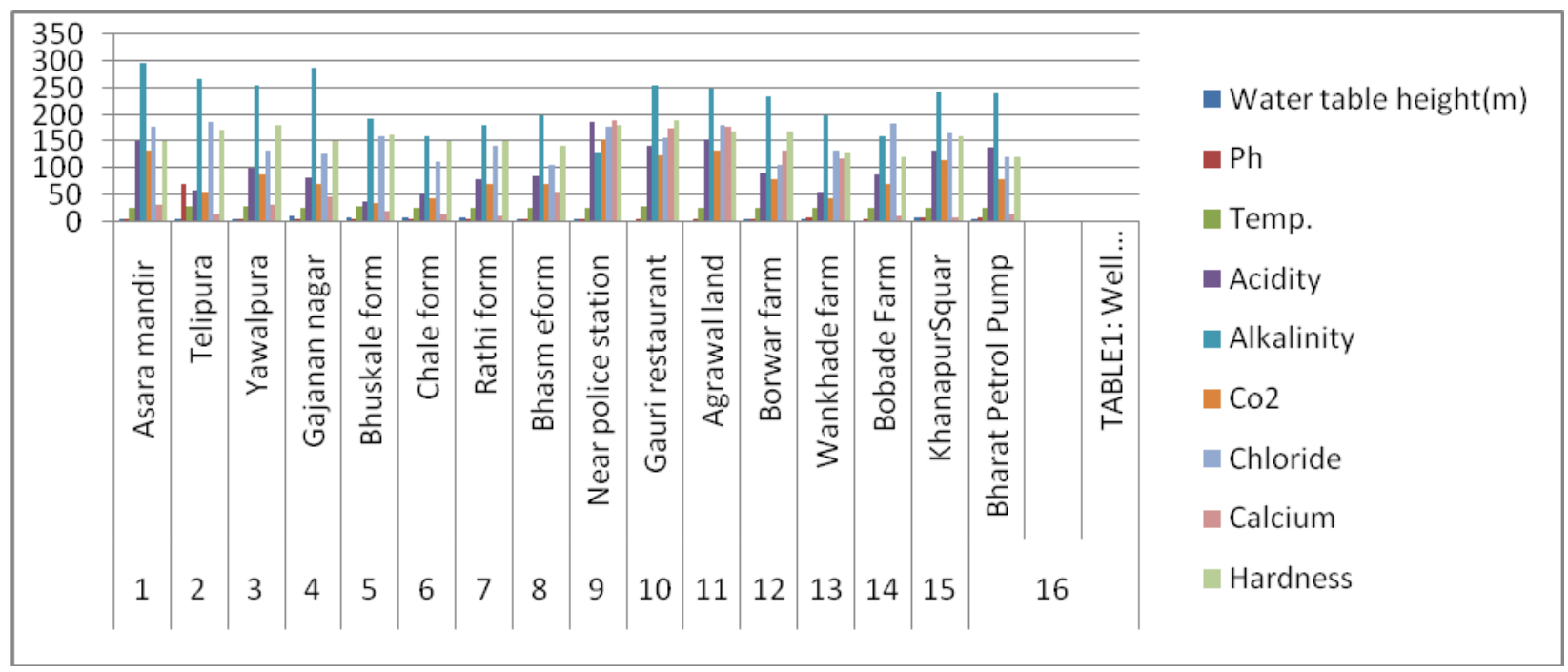

Figure 2: Histogram of Various Parameters Determined for Groundwater Samples Collected from the Study Area

\section{Result and Discussion}

Geological survey has been carry out to suggest the artificial and natural groundwater recharge structures suitable for host rock of sedimentary terrain. According to desalting different element in water samples. Chemical and physical changes are showing in parameters. Physical and chemical parameters of groundwater collected in the water samples for 16 dug wells. The highest $\mathrm{p}^{\mathrm{h}}$ value is 7.655 and lowest value is 7.01 . The temperature of the 
water ranges from $26.5^{0}-29.9^{0}$. Highest value of chloride observed is $185.7 \mathrm{mg} / \mathrm{l}$, whereas, lowest is $106.8 \mathrm{mg} / \mathrm{l}$. Calcium varies from $190 \mathrm{mg} / 1$ to $8.04 \mathrm{mg} / \mathrm{l}$ Showing very high variation. Similarly, hardness ranges from $190 \mathrm{mg} / \mathrm{L}$ to $121 \mathrm{mg} / 1$ Indicating irregular trend because of variable nature of the host sediments. These values are exceptionality high as compared to the standard recommended by [3]. These deficiencies in the water resources of those areas, the people are exposed to different type of diseases like blue baby syndrome, dysentery, jaundice, typhoid, kidney stone, etc.

\section{Conclusion}

The ground water in the study area are fluctuates in weathered jointed and fractured portion of dug well are shown by physical and chemical variation in water samples. Its indicating irregular trend because of host sediment. The source of drinking water are not good for people its harmful and exposed to different type of diseases like blue baby, syndrome, dysentery, jaundice typhoid, kidney stone, etc.

\section{References}

[1] Adyalkar, P.G,(1996), "Paleogeography, framework of sedimentation ,origin of salinity and proposal for its phases amelioration in the purna and upland Alluvial valley of India. Symposium on integrated Approach to management of water and soil of purna and pedhi river basin with special reference to salinity characteristics", Nagpur,p.30-38.

[2] American Public Health Association (APHA),(1992), "Standard method for the examination of water and wasted water", 16 th edition, American public health association".Washington,D.

[3] ISI,(1991), "Indian standard institution -Indian standard specification for drinking water" IS:10500,p.1-5.

[4] Siddiqui,M.A,(2004),"planning Management and Rational Groundwater Development of purna and pedhi basin with Emphasis on Geohydrochemistry of Alluvial Deposits". Unpublished ph.D.Thesis ,SGB Amravati University,Amravati,211p.

[5] Anilkumar D2, (1992), "Environmental chemistry", wiley Eastern Limited, 2nd Edn (1992)p.68.

[6] Abbasi ,S.A (1998), "water quality sampling and analysis .Discovery publicshing house”.

[7] Das ,A.K.(1998): "Nutrient status of the reservoirs in Andhra Pradesh", Geobios,new reports 17(2) 117-123

[8] Fox, C.J.J.(1909): Trans. Farady soc.5:86

[9] Manivaskam,N,(2005) Physicochemical examination of water sewage and industrial effluent,5th Ed . Pragti Prakashan Meerut,

[10] Khan, I.A and khan A.A, (1985) "Physical and chemical condition in seikha Jheelat", Aligarh, Ecol,3,269-274,

[11] Atkins, W.R.and harris G.T.(1924): 1524 sci.proc.R.dublin soc.18:1-21

[12] Sudhir Dahiya and Amarjeet Kaur,(1999) "physic chemical characteristics of underground water in rural areas of Tosham subdivision, Bhiwani district, Haryana", J.Environ Poll, 6(4)

[13] Eizabeth K.M. and Premnath Naik L,(2005)“Effect of polluted water on human health poll”. Res..,24(2),337340

[14] Adyalkar,P.G, (1963) "Palaeogeography, nture and pattern of sedimentation and groundwater potentiality of the purna basin of Maharashtra", proc.Nat,Inst.Sci.Ind.India, Vol.29A,No.1 ,pp 25-45.

[15] Trivedi, R.K. and P.K.Goal (1984) "Chemical nd Biological Method for Water pollution.studies", International Journal of Current Research, pp. 17754-17757.

[16] Wagh S.P; Shrivastava, (2007) V.S.IJEP (27), pp.165-167. 